\title{
Implementation of Programs under the Child-Friendly School Systems (CFSS): Response to Sustainable Development Goals
}

\author{
Marita S. Magat \\ Partido State University, Goa, Camarines Sur, Region V, Philippines
}

\begin{abstract}
The study assessed the implementation of child-friendly school system (CFSS) programs in Camarines Sur, Philippines. Specifically, it presented a profile of programs; assessed the sustainability, relevance, and accessibility; and determined the degree of achievement of the expected outputs of the programs. The study utilized a mixed model of quantitative and qualitative methods. It used a validated researcher-made questionnaire as a data-gathering instrument. Triangulation through structured interview and secondary documents analysis was conducted. Stratified and random sampling was used to determine the samples of students and teachers while the fishbowl technique was used to draw samples of public schools both in secondary and elementary levels in the whole province of Camarines Sur. Total enumeration of school heads was considered in the Key Informants Interview (KII).
\end{abstract}

The study reveals that majority of the programs were relevant, accessible, and sustainable. The achievement of the CFSS outcomes such as retention rate and percentage of wellnourished children are relatively satisfactory while the Mean Percentage Score (MPS) in National Achievement Test (NAT) is low average. The programs addressed Goal 2 (Zero Hunger); Goal 3 (Good Health and Well-Being); Goal 4 (Quality Education); Goal 6 (Clean Water and Sanitation); Goal 13 (Climate Action) and Goal 16 (Peace, Justice and Strong Institutions) of the UN Sustainable Development Goals. The programs that were commonly implemented by school respondents are Brigada Eskwela Plus; Youth for Environment in School (YES); Every Child a Reader Program (ECARP). Massive anti-child labor and anti-bullying campaigns; intensified linkages and resource generation; recovery and sustainability measures for inactive programs which are relevant but no longer implemented were some of the recommendations.

Keywords- Child-Friendly Schools, Implementation, Sustainable Development Goals

\section{INTRODUCTION}

$\mathrm{T}$ he success of every child and his future depends on the quality of education he receives. Educating the child should be the state's utmost priority to produce a community of productive citizens. Quality education establishes a child's lifelong skills in coping with the CFS challenges in the $21^{\text {st }}$ century.

A little over twenty-five (25) years after signing the World Declaration on Education for All (EFA), some countries have made great headway in ensuring universal basic education. Despite the 1994 EFA Declaration, education for all still has not been reached. Some 75 million children were not enrolled or dropped out of school in 2009 according to United Nations International Children's Emergency Fund (UNICEF, 2009). Thus efforts to advance education have become synonymous with ensuring that every child is in school (UNESCO 205) This was overtaken by issues crucial to education such as quality and excellence. The Philippines is one of the countries affected by this trend.

As a response to this issue on quantity versus quality in education, the Philippines, through Republic Act No. 10533, otherwise known as "Enhanced Basic Education Act of 2013" declares that the state shall establish, maintain and support a complete, adequate, and integrated system of education relevant to the needs of the people, the country and society-at-large". Even before 2013, the Department of Education adopted the Child-Friendly School System (CFSS) and has caused the implementation throughout the country with the support of UNICEF.

CFSS is characterized by "inclusivity, health, protection, effectiveness, and involvement of families and communities". This is a framework that allows progress towards establishing a total learning environment that will help children become their best by acquiring the basic competencies and the proper physical, and emotional state that whelp them face the challenges of the century. CFSS aims "to move schools and education systems progressively towards quality standards, addressing all elements that influence the well-being and rights of the child as a learner, while improving other school functions in the process" (Tuncel, et.al. 2018).

According to Wehella (2017), UNICEF envisions CFSS based on three interrelated, interactive, and complementary principles, namely: inclusiveness, childcenteredness, and democratic participation. UNICEF's elaborated model of CFSS features seven dimensions, namely: inclusive and rights-based; gender-sensitive; effective teaching and learning; health and health-promoting; safe, community-engaged and participatory; and effective policies, planning, management, and monitoring (UNICEF, 1999).

These seven dimensions of CFSS were translated into seven goals by the Department of Education, namely: 1 . Encourage child participation in school and community; 2. 
Enhance children's health and well-being; 3. Guarantee safe and protective spaces for children; 4. Encourage enrollment and competition; 5. Ensure children's high academic achievement and success; 6. Raise teachers' morale and motivation; and 7. Mobilize community support for education. The seven dimensions of CFSS were anchored on the following UN Sustainable Development Goals (SDGs): good health and well-being; quality education; and clean water and sanitation. The objective of SDGs is to set universal goals that meet the urgent environmental, political, and economic challenges facing the world. They were adopted by UN member states in answer to the universal call to action to end poverty, protect the planet, and ensure that all people enjoy peace and prosperity by 2030 (UN 2019).

In the country report of child-friendly schools evaluation in the Philippines, the focus was on the extent CFSS promoted child-centered and effective environment; physical health; an environment that promotes security and psychosocial health; an environment that responds to diversity, inclusion, gender sensitivity, and equality; and involvement of families and communities.

Godfrey, et.al, (2012) created indicators for evaluating CFSS initiative using psychometric properties of student-perceived measures of school quality. Students from across the nations such as the Philippines, Nicaragua, and South Africa revealed a core set of items that characterized an emotionally-supportive climate; a challenging studentcentered learning environment; a safe, inclusive, and respectful climate. The results suggested that the CFSS Conditions for Learning Survey may be used to create both reliable cross-national and country-specific indicators for school quality and to provide a blueprint for future psychometric work in the field of child and education policy.

Cobanoglu, et.al. (2018) assessed child-friendly schools by identifying to what extent the teachers, principals, and secondary school students chosen randomly perceived their schools as child-friendly. They used Richer-made ChildFriendly School Scales. Results revealed that CFSS characteristics of schools changed according to the socioeconomic level of the school, the gender of the students, and the grade level. It was recommended that the child-friendly programs be made more functional and sustainable and the teachers' knowledge about CFSS and its variables be improved through in-service training.

Lacrampe (2017) studied children's participation in student government in child-friendly schools in Kenya. Her paper looked into the objectives of the initiatives and how they have been implemented and how they facilitated improvements in children's education and the necessary conditions for the long-term success of the initiatives. It was found out that successes in the implementation include the provision of health education; decision-making initiatives for student government; family and community participation; the shift from teacher-centered to student-centered techniques; and the creation of an environment where females are safe.
UNICEF cited by Shapiro (2015) emphasized the need for a summative evaluation of the CFSS to draw out the lessons learned and to provide information about the effectiveness of a program. The evaluation tool should include those for both monitoring (process) and evaluation (outcomes) because it is geared towards learning from what CFSS are doing, how, and how well they are doing it.

Assessment of implementation of schools' childfriendly projects is significant to public schools to measure the progress of the CFSS; to determine and improve effectiveness; and to improve monitoring and efficiency. Assessment of implementation of CFSS may also be helpful in identifying problems and causes; encouraging actions by suggesting possible solutions; sharing experiences to prevent others from making similar mistakes; and encouraging similar methods or best practices. Consequently, in this study, the existing school programs under the Child-Friendly Schools Systems (CFSS) in public schools in Camarines Sur and their alignment with the Sustainable Development Goals are investigated. It aimed to generate data that will serve as inputs to decision making, policy formulation, planning, management, and monitoring of the programs.

\section{Objectives of the Study}

The main objective of this study is to assess the implementation of programs under the child-friendly school system of selected public elementary and secondary schools in Camarines Sur, Philippines, and their alignment to UN sustainable development goals. Specifically, it aimed to:

1. identify the implementation profile of the programs of public elementary and secondary schools;

2. determine the relevance, accessibility, and sustainability of the programs; and

3. determine the degree of achievement of expected outputs and outcomes of the programs.

\section{METHODOLOGY}

This study utilized the mixed model approach consisting of quantitative and qualitative research methods. The quantitative method was employed through the researcher-made questionnaires and secondary data while the qualitative study further supported the documents through key informants' surveys and structured interviews.

The study made use of a validated researcher-made survey questionnaire consisting of five (5) parts. Part I elicited data on the general profile of the programs of public schools in alignment with the Child-Friendly Schools (CFS) System. It particularly queried the descriptions of the programs and their legal bases for implementation. Part II is a questionnaire on the relevance, accessibility, and sustainability of the programs which were rated using the four-point Likert scale. Part III is a tool to elicit the degree of accomplishment of the expected outputs and outcomes of the child-friendly schools. Part III was supported by secondary data. This questionnaire was face and content validated by three (3) personnel in the 
Department of Education who have expertise in the field of CFSS. A validation checklist was used and recommendations per item in the questionnaire were incorporated in the final instrument.

The study utilized selected public schools in the municipalities of Camarines Sur as respondents. Two (2) schools each from elementary and secondary levels from each District were taken as samples. The fishbowl method was used to draw the sample schools. However, in the case of Districts with only one (1) public secondary school in the mainland, fishbowl method was no longer applied.

On the other hand, it used stratified sampling techniques to determine the sample population of pupils, students, and teachers in each school. The Slovin formula was used to come up with the sample respondents both for teachers and students. The fishbowl technique in drawing individual samples was employed to give each member of the population the equal chance to be drawn as respondents. $100 \%$ of school heads of the sampled schools both in the elementary and secondary schools were considered as key informants (KI) and interviewees. All of the participants were properly informed of the purpose of the study.

The approval of the Department of Education (DepEd), Division of Camarines Sur as well as District DepEd offices was sought. The assistance of enumerators was availed in the administration of the questionnaire. The triangulation through structured interview, key informants' survey, and secondary documents was employed to validate the data generated in the questionnaire.

The data were tallied and subjected to statistical computations. They were presented in tables and graphs and analyzed. Transcriptions of the structured interview are presented in some parts of the results and discussion of this study to convey genuineness of the data.

\section{DISCUSSIONS}

\section{A. Profile of the CFSS Programs}

Table 1 presents the profile of the CFSS programs of the ten (10) selected public schools in Camarines Sur. It shows that Brigada Eskwela, also known as National Schools Maintenance Week, a volunteerism program between the school and the community aimed at preparing the school physical environment for the opening of classes, is implemented by all of the respondent schools. It is followed by Youth for Environment in Schools (YES), a program that was established to serve as a venue for students' actions towards safeguarding, protecting, and conserving the environment. This is implemented by 8 respondent schools. Every Child a Reader Program (ECARP), a national program that aims to make every Filipino child a reader at his own level and equip him/her with strategic reading and writing skills, is implemented by 6 schools. Gulayan sa Paaralan Program (GPP) is a school-based program for elementary and secondary schools designed to address malnutrition and promote vegetable production and consumption among school children, is being implemented by six (6) respondent schools. Further, the School-Based Feeding Program (SBFP), a program that set a record of 3.5 million student-beneficiaries for 2019-2020, which aims to address hunger, contribute to the improvement of nutritional status, and improve the school performance and learning outcomes is also implemented by six (6) respondent schools.

The CFSS programs which are least implemented by the respondent schools were WATCH, WOW, WinS, Child Protection Program, and Disaster Risk Management. The Project WATCH (We Advocate Time Consciousness and Honesty) is aimed to strengthen punctuality and honesty as core values in promoting personal and national development. The War on Waste (WOW) is a crusade of public and private elementary and secondary schools to instill the values of thrift, economy, and prudence in using resources and to contribute to the national efforts for the conservation of resources. Wash in School (WinS) promotes a clean and safe environment, correct hygiene and sanitation practices among students. Child Protection Program aims to protect students from abuse, violence, exploitation, discrimination, bullying, and other forms of abuse. Disaster Risk Management Program aims to implement mechanisms that prepare, protect, and increase resiliency in the face of disaster.

On the other hand, YES (15 years) and Brigada Eskwela (14 years) are the oldest among the programs in terms of implementation. The Department of Education (DepEd) first piloted the CFSS in 2001, since then the number of CFSS schools has steadily increased to 5, 000 out of 40,763 by 2008 . The oldest CFSS program implemented in Camarines Sur was found to be implemented sixteen (16) years ago by an elementary school. That means CFSS was implemented in the province three (3) years after it was piloted in the Philippines and thirteen (13) years after the adoption of United Nations member countries in 1989 through the UN Convention on the Rights of Children.

Moreover, it was found out that the programs implemented were anchored on the UN Sustainable Development Goals (SDG). Three of the CFSS programs were anchored on Goal 13- Climate Action, namely: Youth for Environment in School (YES); War on Waste; and Disaster Risk Management Program. Two programs address Goal 2- Zero Hunger, namely: School-Based Feeding Program and Gulayan sa Paaralan. Another two programs are aligned with Goal 16- Peace, Justice and Strong Institutions, namely: Child Protection Program and Project WATCH. Still others were anchored on Goal 17- Partnership and Collaboration, namely: Gulayan sa Paaralan and Brigada Eskuwela. The latter is also a manifestation of Goal 3-Good Health and Well-Being. Every Child a Reader Program (ECARP) is in consonance with Goal 4-Quality Education and Wash in School (WinS) addressed Goal 6-Clean Water and Sanitation. Interestingly, these findings suggest that schools had proven to be the implementing arms of the government in attaining the goal of transforming the world 
into sustainable communities by 2030. The CFSS programs implemented by the respondent schools addressed seven (7) out of the seventeen (17) UN development goals and were long been implemented since the launching and pilot testing in 2001 .

Table I: Profile Of The Cfss Programs Of Selected Public Schools

\begin{tabular}{|c|c|c|c|c|c|}
\hline CFSS Programs & $\begin{array}{l}\text { No. of } \\
\text { Schoo } \\
\text { ls }\end{array}$ & $\begin{array}{c}\text { Years of } \\
\text { Implementati } \\
\text { on }\end{array}$ & Legal Bases & Implementation Goals & $\begin{array}{l}\text { Alignment to UN Sustainable Development } \\
\text { Goals }\end{array}$ \\
\hline Brigada Eskwela & 10 & 14 & $\begin{array}{l}\text { DedEd Memo \# } \\
24, \text { s.2008 }\end{array}$ & $\begin{array}{l}\text { Preparation of the school } \\
\text { physical environment through } \\
\text { partnership with community }\end{array}$ & $\begin{array}{l}\text { Goal 3-Good Health and Well-Being } \\
\text { Goal 17-Partnership and Collaboration }\end{array}$ \\
\hline $\begin{array}{l}\text { Youth for Environment } \\
\text { in School (YES) }\end{array}$ & 8 & 15 & $\begin{array}{l}\text { DedEd Memo \# } \\
72, \text { s.2003 }\end{array}$ & $\begin{array}{c}\text { Inculcation of environmental } \\
\text { responsibility }\end{array}$ & Goal 13-Climate Action \\
\hline $\begin{array}{l}\text { Every Child A Reader } \\
\text { Program (ECRAP) }\end{array}$ & 6 & 5 & $\begin{array}{l}\text { DedEd Memo \# } \\
45, \text { s.2002 }\end{array}$ & Improvement of reading skills & Goal 4- Quality Education \\
\hline Gulayan sa Paaralan & 6 & 5 & $\begin{array}{l}\text { DedEd Memo \# } \\
\text { 293, s.2007 }\end{array}$ & $\begin{array}{l}\text { Maintenance of vegetable } \\
\text { gardening through } \\
\text { community collaboration }\end{array}$ & $\begin{array}{c}\text { Goal 2-Zero Hunger } \\
\text { Goal 17-Partnership and Collaboration }\end{array}$ \\
\hline $\begin{array}{l}\text { School Based Feeding } \\
\text { Program (SBFP) }\end{array}$ & 6 & 3 & $\begin{array}{l}\text { DepEd Order \# } \\
\text { 39, s. } 2017\end{array}$ & $\begin{array}{l}\text { Improvement in attendance, } \\
\text { achievement, growth and } \\
\text { other health outcomes }\end{array}$ & Goal 2-Zero Hunger \\
\hline $\begin{array}{c}\text { Project WATCH (We } \\
\text { Advocate Time } \\
\text { Consciousness and } \\
\text { Honesty) } \\
\end{array}$ & 5 & 4 & $\begin{array}{l}\text { DepEd Order \# } \\
410, \text { s. } 2009\end{array}$ & $\begin{array}{l}\text { Improvement in attendance } \\
\text { and punctuality and advocacy } \\
\text { campaign on honesty }\end{array}$ & $\begin{array}{l}\text { Goal 16-Peace, Justice and Strong } \\
\text { Institutions }\end{array}$ \\
\hline War on Waste (WOW) & 4 & 4 & $\begin{array}{l}\text { DepEd Order \# } \\
54, \text { s. } 1995\end{array}$ & $\begin{array}{c}\text { Awareness of four Rs } \\
\text { (Reduce, Recycle, Reuse and } \\
\text { Repurpose) }\end{array}$ & Goal 13-Climate Action \\
\hline Wash in School (WinS) & 4 & 3 & $\begin{array}{c}\text { DepEd Order \# } \\
10, \text { s. } 2016 \\
\end{array}$ & $\begin{array}{l}\text { Advocacy on sanitation and } \\
\text { hygiene }\end{array}$ & Goal 6- Clean Water and Sanitation \\
\hline $\begin{array}{l}\text { Child Protection } \\
\text { Program }\end{array}$ & 4 & 4 & $\begin{array}{l}\text { DepEd Order \# } \\
40, \text { s. } 2012\end{array}$ & $\begin{array}{l}\text { Information and action } \\
\text { campaign on right and } \\
\text { privileges of a child }\end{array}$ & $\begin{array}{l}\text { Goal 16-Peace, Justice and Strong } \\
\text { Institutions }\end{array}$ \\
\hline $\begin{array}{c}\text { Disaster Risk } \\
\text { Management System }\end{array}$ & 2 & 4 & $\begin{array}{l}\text { DepEd Order } \\
\# 21, \text { s.2015 }\end{array}$ & $\begin{array}{l}\text { Awareness campaign on } \\
\text { safety during calamities }\end{array}$ & Goal 13-Climate Action \\
\hline
\end{tabular}

B. Relevance, Accessibility, and Sustainability of the CFSS Programs

Table 2 presents the relevance, accessibility, and sustainability of the CFSS projects of the selected public schools in Camarines Sur. A five-point Likert scale with the corresponding descriptions used in describing the relevance, accessibility, and sustainability of the CFSS programs was used. The data were gathered through the administration of validated researcher-made questionnaires to randomly sampled respondents which include principals, teachers, and pupils.

It can be gleaned from the table that the CFSS programs of selected schools in Camarines Sur are generally assessed as relevant ( $\mathrm{M}=3.95)$; accessible $(\mathrm{M}=3.91)$; and sustainable $(\mathrm{M}=3.68)$. It is interesting to note that in Districts 1, 2, and 5, the CFSS programs were rated as "Highly Relevant" $(M \leq 4.90 \geq 4.0)$. Likewise, CFSS projects in District 2 were rated "Highly Accessible" $(M=4.01)$. Districts 3 and 4 were rated relevant", "accessible", and "sustainable"
$(M \leq 3.90 \geq 3.00)$. Public schools $\mathrm{B}, \mathrm{C}, \mathrm{E}$, and I were rated highly relevant, highly accessible, and highly sustainable $((M \leq 4.90 \geq 4.0)$.

Moreover, it was found out during the KII and FGD that the relevance, accessibility, and sustainability are higher in schools situated in bigger barangays than those in far-flung and small barangays. The sustainability of the programs may also be gleaned from the economic characteristics of the families living near the respondent schools. Elementary and secondary schools located in barangays with a higher incidence of poverty have less sustainable CFSS projects. Thus, the relevance, accessibility, and sustainability of the CFSS programs may be attributed to the economic condition of the location of the school. 
Table II: Relevance, Accessibility, And Sustainability Of The Cfss Programs Of Selected Public Schools

\begin{tabular}{|c|c|c|c|c|c|c|}
\hline \multirow{2}{*}{ District/School } & \multicolumn{2}{|c|}{ Relevance } & \multicolumn{2}{|c|}{ Accessibility } & \multicolumn{2}{|c|}{ Sustainability } \\
\hline & Weighted mean & Description & Weighted mean & Description & Weighted mean & Description \\
\hline \multicolumn{7}{|c|}{ District 1} \\
\hline PS A & 3.20 & $\mathrm{R}$ & 3.29 & A & 3.17 & $\mathrm{~S}$ \\
\hline PS B & 4.95 & HR & 4.53 & HA & 4.02 & HS \\
\hline Ave. & 4.08 & HR & 3.91 & A & 3.60 & S \\
\hline \multicolumn{7}{|c|}{ District 2} \\
\hline PS C & 4.89 & HR & 4.86 & HA & 4.87 & HS \\
\hline PS D & 3.85 & $\mathrm{R}$ & 3.16 & A & 3.01 & S \\
\hline Ave. & 4.37 & HR & 4.01 & HA & 3.94 & S \\
\hline \multicolumn{7}{|c|}{ District 3} \\
\hline PS E & 4.18 & HR & 4.08 & HA & 4.01 & HS \\
\hline PS F & 3.02 & $\mathrm{R}$ & 3.34 & A & 3.00 & $\mathrm{~S}$ \\
\hline Ave. & 3.60 & $\mathrm{R}$ & 3.71 & A & 3.51 & S \\
\hline \multicolumn{7}{|c|}{ District 4} \\
\hline PS G & 4.26 & HR & 4.38 & HA & 3.80 & S \\
\hline PS H & 3.06 & $\mathrm{R}$ & 3.51 & A & 3.03 & $\mathrm{~S}$ \\
\hline Ave. & 3.66 & $\mathrm{R}$ & 3.94 & A & 3.42 & S \\
\hline \multicolumn{7}{|c|}{ District 5} \\
\hline PS I & 4.18 & HR & 4.08 & HA & 4.03 & HS \\
\hline PS J & 3.89 & $\mathrm{R}$ & 3.86 & A & 3.87 & $\mathrm{~S}$ \\
\hline Ave. & 4.04 & HR & 3.97 & A & 3.95 & $\mathrm{~S}$ \\
\hline $\begin{array}{l}\text { Grand Weighted } \\
\text { Mean Ave. }\end{array}$ & 3.95 & $\mathrm{R}$ & 3.91 & A & 3.68 & $\mathrm{~S}$ \\
\hline
\end{tabular}

Legend: PS- Public School

5.00 - Excellently Relevant (ER)/ Accessible (EA)/Sustainable (ES)

4.00 - 4.90 - Highly Relevant (HR)/ Accessible (HA)/Sustainable (HS)

3.00 - 3.90 - Relevant (R)/ Accessible (A)/Sustainable (S)

$2.00-2.90$ - Moderately Relevant (MR) / Accessible (MA)/Sustainable (MS)

1.00 - 1.90 - Not Relevant (NR)/ Accessible (NA)/Sustainable (NS)

C. Degree of Achievement of Expected Outputs and Outcomes of the CFSS Programs of Selected Public Schools

Retention rate is an outcome of CFSS under Dimension 1: encourage children's participation in the school and in the community; Dimension 4: encourage enrolment and competition; and Dimension 5: ensure children's high academic achievement and success. Moreover, the schools' performance in the National Achievement Test (NAT) is an expected outcome of CFSS under Dimension 5. Likewise, the prevalence of well-nourished children in the school is an outcome of CFSS under Goals 2: enhance children's health and well-being.

Retention rate is measured by the number of students who enrolled six (6) or four (4) years ago divided by the number of students who graduated six (6) or four (4) years after. The national achievement test results were taken from secondary data from the school respondents or the Division Office of Camarines Sur. The percentage of well-nourished students was computed through the number of students with ideal Body Mass Index (BMI), absence of tooth decay, and absence of communicable disease divided by the total number of students enrolled.

To interpret retention rate, the following descriptions were used: above 79\%-Outstanding; 70\%-79\%- Very Good; 65\%-70\%- Good; 59\%-65\%- Fair; and below 59\%- Poor. Likewise, the interpretation of NAT results is based on the country's Department of Education records: 76-100 Mean Percentage Score (MPS) is superior; 51-75 MPS is Upper Average; 26-50 MPS is Lower Average; and below 25 is Low. The percentage of well-nourished students is described as the following: Above $91 \%$ is Outstanding; $81 \%-90 \%$ is Very Good; $71 \%-80 \%$ is Good; $51 \%-70 \%$ is Fair; and $26 \%-50 \%$ is Poor.

Table 4 presents the degree of achievement of the expected outputs and outcomes of the CFS programs and projects of the selected public elementary schools in Camarines Sur, Philippines. It shows that the selected schools 
in Camarines Sur have a good retention rate $(\mathrm{M}=67.33)$; a low average performance in the National Achievement Test
(MPS=47.99); and a good percentage of well-nourished school children $(\mathrm{M}=71.3)$.

Table III: Degree Of Achievement Of Expected Outputs And Outcomes Of The Cfss Programs Of Selected Public Schools

\begin{tabular}{|c|c|c|c|c|c|c|}
\hline \multirow{2}{*}{ District/School } & \multicolumn{2}{|c|}{ Retention Rate } & \multicolumn{2}{|c|}{ National Achievement Test } & \multicolumn{2}{|c|}{ Well-Nourished Pupils } \\
\hline & $\%$ & Description & $\%$ & Description & $\%$ & Description \\
\hline \multicolumn{7}{|c|}{ District 1} \\
\hline PS A & 58.85 & Fair & 40.64 & Low Average & 62.41 & Fair \\
\hline PS B & 65.74 & Good & 47.79 & Low Average & 71.05 & Good \\
\hline Ave. & 62.30 & Good & 44.22 & Low Average & 66.73 & Fair \\
\hline \multicolumn{7}{|c|}{ District 2} \\
\hline PS C & 79.35 & Very Good & 53.23 & Upper Average & 81.23 & Very Good \\
\hline PS D & 66.05 & Good & 49.18 & Low Average & 71.11 & Good \\
\hline Ave. & $\mathbf{7 2 . 7 0}$ & Very Good & 51.20 & Upper Average & 76.17 & Good \\
\hline \multicolumn{7}{|c|}{ District 3} \\
\hline PS E & 60.09 & Fair & 43.87 & Low Average & 64.98 & Fair \\
\hline PS F & 79.08 & Very Good & 51.14 & Upper Average & 82.65 & Very Good \\
\hline Ave. & 69.58 & Good & 47.50 & Low Average & 73.82 & Good \\
\hline \multicolumn{7}{|c|}{ District 4} \\
\hline PS G & 70.04 & Very Good & 52.37 & Upper Average & 72.72 & Good \\
\hline PS H & 59.09 & Fair & 42.95 & Low Average & 63.89 & Fair \\
\hline Ave. & 64.56 & Good & 47.66 & Low Average & 68.30 & Good \\
\hline \multicolumn{7}{|c|}{ District 5} \\
\hline PS I & 70.00 & Very Good & 48.97 & Low Average & 71.09 & Good \\
\hline PS J & 65.05 & Good & 49.75 & Low Average & 72.76 & Good \\
\hline Ave. & 67.52 & Good & 49.36 & Low Average & 71.92 & Good \\
\hline Grand Ave. & 67.33 & Good & 47.99 & Low Average & 71.39 & Good \\
\hline
\end{tabular}

Legend: PS- Public School

It can be gleaned from the table that among the five (5) Districts, District 2 has the highest retention rate with $72.70 \%$ described as "Very Good". The relevance, accessibility, and sustainability of CFS programs in this District are higher than those of the other four (4) Districts. These four (4 ) Districts have "good" retention rates which range from 62.30 to 69.58 . On the other hand, the schools in urban had significantly higher retention rates than the schools in far-flung barangays. Similarly, this may be attributed to the higher degree of relevance, accessibility, and sustainability of CFSS projects in these schools. Moreover, the NAT results of District 2 was the highest with 51.20 described as "Upper Average". The rest of the sampled schools had "Low Average" NAT scores.

\section{CONCLUSIONS}

The following conclusions were made:

1. Brigada Eskwela, a volunteerism program aimed at preparing the school physical environment for the opening of classes, is the most commonly implemented CFSS project among the selected public schools. The oldest implemented project was Youth for Environment (YES), a program on environmental awareness which was found to be implemented sixteen(16) years ago, three (3) years after CFSS was piloted in the Philippines, and thirteen (13) years after the adoption of United Nations member countries of the UN Convention on the Rights of Children. The programs identified were found to be compliant with CFSS Goals: encourage participation to school and community; enhance health and well-being; guarantee safe and protective spaces; encourage enrollment and competition; ensure high academic achievement and success; and mobilize community support. Likewise, CFSS programs were in consonance with the UN sustainable development goals of Zero Hunger; No Poverty; Good Health and Well-Being; Quality Education; Climate Action; Sustainable Communities; and Strong Institutions. 
2. The CFSS programs of respondent schools are relevant ( $M=3.95)$; accessible $(M=3.91)$; and sustainable $(M=3.68)$. The relevance, accessibility, and sustainability are higher in elementary schools than in secondary schools. Relevance, accessibility, and sustainability are higher in schools situated in bigger barangays than those in far-flung and small barangays. The sustainability of the programs may also be attributed to the economic characteristics of the families living near the respondent schools. Elementary and secondary schools located in barangays with a higher incidence of poverty have less sustainable CFSS projects.

3. The respondent schools have a good retention rate of 67.33\%; a low average Mean Percentage Score (MPS) of 47.99 in the National Achievement Test; and a good percentage of well-nourished students of $71.39 \%$.

\section{RECOMMENDATIONS}

Based on the findings and conclusions, the following are recommended:

1. Intensified awareness campaigns on CFSS may be conducted to impact the attitudes of the stakeholders in schools with relatively low accessibility and relevance as perceived by the stakeholders.

2. Massive anti-child labor and anti-bullying campaigns may be given emphasis for sustainability, relevance, and accessibility of the Child Protection Program.

3. Strong linkages and resource generation are recommended for greater sustainability and accessibility of the programs.

4. Recovery and sustainability measures for inactive CFS programs and projects may be pursued.

5. Improved effective teaching-learning strategies, adequate learning materials and facilities, continuous training, and professional development of teachers may be sustained to improve performance in the national achievement test which is an outcome indicator of the CFSS programs.

6. Strict implementation of sound policies that are childfriendly may be further pursued.

7. Impact study of the CFSS projects may be conducted.

8. Studies on the attributability of relevance, accessibility, and sustainability of CFSS programs to certain factors may be conducted.

\section{ACKNOWLEDGMENT}

This research is institutionally funded by Partido Sate University, Camarines Sur, Philippines. Its conduct was granted permission by the Department of Education, Division of Camarines Sur, Philippines.

\section{REFERENCES}

[1] United Nations International Children Emergency Fund (UNICEF). (2009). Assessing Child-Friendly Schools: Manual, UNICEF, New
York, USA. $\quad$ Retrieved from htpp://www.unicef.org/eapro/Assessing_CFS.pdf

[2] United Nations International Children Emergency Fund (UNICEF). (2015). Child-Friendly Schools: Manual, UNICEF, New York, USA. Retrieved from htpp://www.unicef.org/lifeskills/index_7260.html

[3] Tuncel, et. al., (2018). Child-Friendly Schools: An Assessment of Secondary Schools. Universal Journal of Educational Research, 6(3), 466-477. DOI: 10.13189/ejer.2018.060313.

[4] Wehella, M. (2014). School-based Management Initiatives in Sri Lanka: Policy into Practice. Unpublished Doctoral Dissertation, University of Sussex OnLine Journal. Retrieved from http://sro.sussex.ac.uk/.

[5] United Nations International Children Emergency Fund (UNICEF). (1999). Child-Friendly Schools Evaluation: Country Report for Philippines. United Nations Children's Fund, New York, USA

[6] United Nations (UN). (2019). Un Sustainable Development Goals. New York, USA. Retrieved from https://www.un.org/sustainabledevelopment/sustainabledevelopment-goals/

[7] Aguilar, J. 2011. Child-Friendly School as an Entry Point for Democratization of Educational System and Learning, Paper presented to the Ministerial Conference on "Education as an Investment into the Future of Asia", Tashkent, April 2011. Retrieved from www.osce.orgcio28968.

[8] United Nations International Children Emergency Fund (UNICEF), (2009). Child-Friendly Schools Evaluation: Country Report for the Philippines. United Nations Children's Fund, New York, USA. Retrieved

from http://www.unicef.org/evaldatabase/index 58798.html .

[9] United Nations (UN). (2019). Un Sustainable Development Goals. New York, USA. Retrieved from https://www.un.org/sustainabledevelopment/sustainabledevelopment-goals/

[10] Godfrey, E.,( 2012). Cross-national measurement of school learning environments: Creating indicators for evaluating UNICEF's Child-Friendly Schools Initiative. Child and Youth Services Review, 34(3), 546-557.

[11] Cobanoglu, F, et.al., (2018). Child-Friendly Schools: An assessment of Secondary Schools. Universal Journal of Educational Research, 466-477. DOI 10.13189.

[12] Lacrampe, R.( 2017). Children's Participation as a Feature of Educational Reform in Kenya: An Analysis of the Child-Friendly School Framework and Children's Government. University of Ottawa Research Journal, retrieved from http://ruor.uottawa.ca/bitstream/10393/36671/Lacrampe Rachel.

[13] Shapiro, J. (2005). Monitoring and Evaluation, CIVICUS, South Africa, $\quad$ p. $\quad 3 . \quad$ Retrieved from http://www.schoolnetafrica.net/fileadmin/resources/Monitoring an d Evaluation.pdf

[14] Department of Education, (2008).Institutionalization of Brigada Eskwela Program, DepEd Memo \# 24, s.2008, http://www.deped.gov.ph

[15] Department of Education, (2003).Establishment of Youth for Environment in Schools (YES) Program, DepEd Memo \# 72, s.2003, http://www.deped.gov.ph

[16] Department of Education, (2002).Reading Literacy Program in the Elementary Schools, DepEd Memo \# 45, s.2002, http://www.deped.gov.ph

[17] Department of Education, (2007). Gulayan sa Paaralan Program, DepEd Memo \# 72, s. 2007, http://www.deped.gov.ph

[18] Department of Education, (2017).Operational Guidelines on the Implementation of School-Based Feeding Program, DedEd Memo \# 39, s.2017, http://www.deped.gov.ph

[19] Department of Education, (2009).Guidelines in the Establishment of WATCH Schools (We Advocate Time Conciousness and Honesty in Schools) , DedEd Memo \# 410, s.2009, http://www.deped.gov.ph

[20] Department of Education, (1995). War on Waste Crusade, DedEd Memo \# 54, s. 1995, http://www.deped.gov.ph 
International Journal of Research and Innovation in Social Science (IJRISS) |Volume V, Issue XI, November 2021|ISSN 2454-6186

[21] Department of Education, (2016). Policy and Guidelines for the Comprehensive Water, Sanitation and Hygiene in Schools (WINS) Program, DedEd Memo \# 10, s. 2016, http://www.deped.gov.ph

[22] Department of Education, (2012). DEPED Child Protection Policy, DedEd Memo \# 40, s.2012, http://www.deped.gov.ph
[23] Department of Education, (2015). Disaster Risk Reduction and Management Coordination and Information Management Protocol, DedEd Memo \# 21, s.2015, http://www.deped.gov.ph 